\title{
NOTE
}

\section{Marine virioplankton produced by infected Ectocarpus siliculosus (Phaeophyceae)}

\author{
Dieter G. Müller \\ Fakultät für Biologie der Universität, W-7750 Konstanz, Germany
}

\begin{abstract}
The benthic marine brown alga Ectocarpus siliculosus can be infected by a virus which is expressed in reproductive organs of the host. In cultures, liberation of virus particles was stimulated by addition of fresh culture medium together with a rise in temperature, suggesting the incoming tide as a triggering factor in the natural habitat.
\end{abstract}

Ultra-small particles between 20 and $200 \mathrm{~nm}$ diameter suspended in aquatic habitats are referred to as femto-plankton (Sieburth et al. 1978). Direct counts in coastal and offshore waters yield high numbers of up to $10^{8}$ particles $\mathrm{ml}^{-1}$ (Bergh et al. 1989). Proctor \& Fuhrman (1990) found significant numbers of phageinfected bacteria and cyanophytes, which therefore can be a potential source of marine planktonic viruses. While Borsheim et al. (1990) considered viruses from eukaryotic hosts to be of minor significance, Suttle et al. (1990) found a strong impact of virus samples from natural habitats on the vitality of laboratory cultures of unicellular eukaryotic phytoplankton species such as diatoms, cryptophytes and prasinophytes.

The benthic brown alga Ectocarpus siliculosus has been shown to act as a host for a marine virus (Müller et al. 1990). Laboratory cultures were used to study virus release and to estimate the productivity of this system.

Material and methods. Virus-infected gametophytes of Ectocarpus siliculosus (Dillw.) Lyngb. isolated from the New Zealand coast (Müller 1991) were used to generate a sporophyte strain with rich and stable virus expression. Bacteria-free stock cultures were maintained in Petri dishes on Provasoli ES-medium solidified with $1 \%$ agar. Four to $6 \mathrm{wk}$ after transfer to sterile liquid medium the E. siliculosus plants reached maturity. Release of virus clouds was observed in microscopic mounts under dark field illumination on a Leitz dissecting scope at $63 \times$ magnification. Size of virus particles and their number per sporangium compartment were derived from electron micrographs (Figs. $1 \& 3$ ).
Observations. A typical infected Ectocarpus siliculosus sporophyte of a few $\mathrm{cm}$ in length forms several hundred non-functional sporangia (Fig. 2). Each compartment in such a sporangium contains an average of $2 \times 10^{6}$ virus particles. Quantitative measurements gave values between 1.7 and $3.2 \times 10^{13}$ virus particles per $g$ fresh weight of infected algae. Virus liberation was stimulated by transfering the host plants to fresh culture medium and raising temperature from 12 to $20^{\circ} \mathrm{C}$. Sporangial walls burst, and masses of virus particles were discharged into the surrounding seawater (Figs. 4 \& 5). They showed intense Brownian movement and fanned out to plumes, which gradually dispersed and became invisible after 10 to $15 \mathrm{~min}$.

The chemical and temperature stimuli inducing virus release also synchronize discharge of gametes and zoospores in healthy Ectocarpus siliculosus plants. These naked, free-swimming cells are attacked by the virus and used as entrance sites into a new host (Müller 1991). Since E. siliculosus grows in the intertidal zone, the stimulus of re-immersion with the rising tide is likely to trigger virus discharge, zoid release and infection processes in the field.

The laboratory observations described here demonstrate for the first time the existence of a potent eukaryotic virus production system in the marine coastal environment. Further studies in the natural habitat are needed to evaluate its ecological significance.

\section{LITERATURE CITED}

Bergh, O., Borsheim, K. Y., Bratbak, G., Heldal, M. (1989). High abundance of viruses found in aquatic environments Nature, Lond. 340: 467-468

Børsheim, K. Y., Bratbak, G., Heldal, M. (1990). Enumeration and biomass estimation of planktonic bacteria and viruses by transmission electron microscopy. Appl. envir Microbiol. 56 : 352-356 


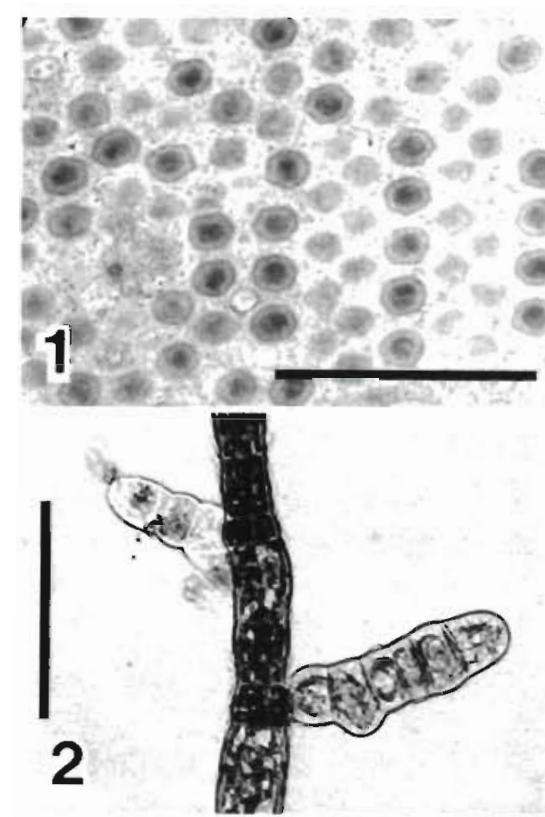

\section{4}

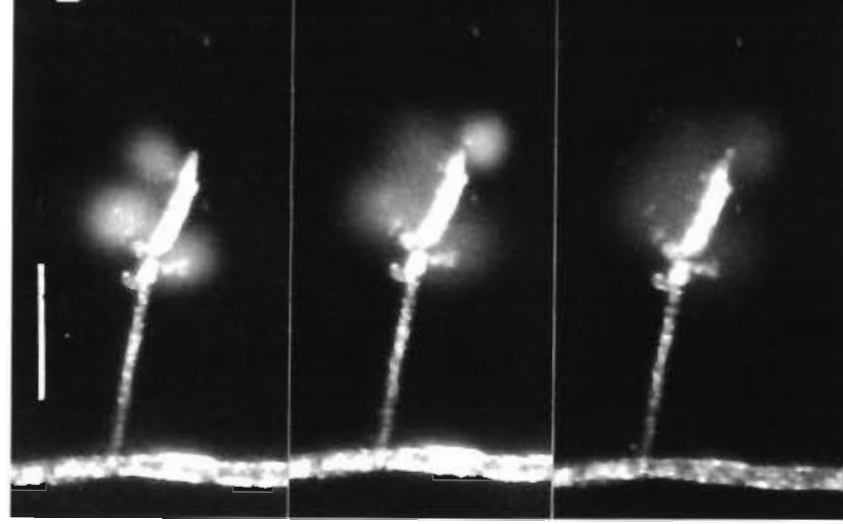

Müller, D. G. (1991). Mendelian segregation of a virus genome during host melosis in the marine brown alga Ectocarpus siliculosus. J. Plant Physiol. 137.739-743

Müller, D. G., Kawai, H., Stache, B., Lanka, S. (1990). A virus infection in the marine brown alga Ectocarpus siliculosus. Botanica Acta 103: 72-82

Proctor, L. M., Fuhrman, J. A. (1990). Viral mortality of marine bacteria and cyanobacteria. Nature, Lond. 343: 60-62

This note was submitted to the editor
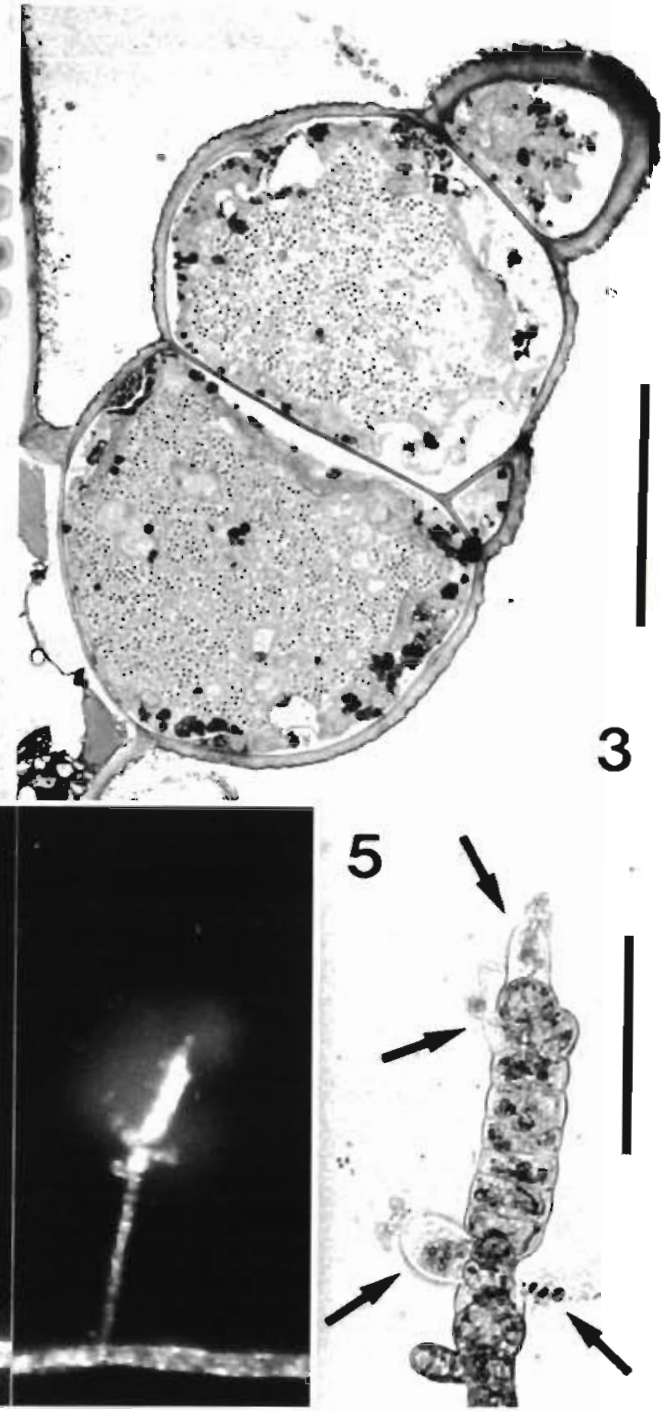

Figs. 1 to 5. Ectocarpus siliculosus. Fig. 1. EM thin section showing virus particles in the sporangium of an infected plant. Scale bar $=$ $1 \mu \mathrm{m}$. Fig. 2. Sporangia of an infected host with intact and burst virus compartements. Scale bar = $100 \mu \mathrm{m}$. Fig. 3. Longitudinal EM section through a sporangium with virus expression. Scale bar $=$ 10 um. (From Müller 1991.) Fig. 4. Virus masses emerging from bursting compartments of a sporangium. Successive dark field exposures 6,12 and $19 \mathrm{~min}$ after mounting. Scale bar $=200 \mu \mathrm{m}$. Fig. 5. Same sporangium at $16 \mathrm{~min}$ in bright field. Arrows indicate remnants of cells burst in Fig. 4 Scale bar $=100 \mu \mathrm{m}$
Sieburth, J. M., Smetacek, V., Lenz, J. (1978). Pelagic ecosys tem structure: heterotrophic compartments of the plankton and their relationship to plankton size fractions. Limnol. Oceanogr 23: 1256-1263

Suttle, (: A., Chan, A. M., Cottrell, T (1990). Infection of phytoplankton by viruses and reduction of primary productivity. Nature, Lond. 347 467-469

Manuscript first received: March 6, 1991 Revised version accepted June 25, 1991 